\title{
Proline Endopeptidase Protein Cleavage Reagent
}

National Cancer Institute

\section{Source}

National Cancer Institute. Proline Endopeptidase Protein Cleavage Reagent. NCI

Thesaurus. Code C161891.

A protein cleavage reagent comprised of the proline endopeptidase neurolysin that cleaves proteins into peptides at the C-terminal side of a proline residue. 